\title{
SYMMETRICAL AND ASYMMETRICAL MESO-SUBSTITUTED PORPHYRINS AND Zn-METALLOPORPHYRINS IN GOLD COLLOID ENVIRONMENT. OPTICAL PROPERTIES AND EVALUATION OF ANTIBACTERIAL ACTIVITY
}

\author{
LUMINIȚA SALAGEANU ${ }^{1,2}$, DELIA MUNTEAN ${ }^{3,4 *}$, MONICA LICKER $^{3,4}$, ANCA LASCU $^{1}$, \\ DIANA ANGHEL ${ }^{1}$, EUGENIA FAGADAR-COSMA ${ }^{1}$
}

${ }^{1}$ Institute of Chemistry, Romanian Academy, 24 Mihai Viteazul Avenue, 300223, Timișoara, Romania

${ }^{2}$ Health Insurance House Timiş, 4 Corbului Street, 300239, Timişoara, Romania

3 "Victor Babeș" University of Medicine and Pharmacy, 2 Eftimie Murgu Square, 300041, Timișoara, Romania

4 "Pius Brînzeu”" Emergency Clinical County Hospital, 156 Liviu Rebreanu Boulevard, 300723, Timișoara, Romania

*corresponding author: deliacristimuntean@yahoo.com

Manuscript received: February 2019

\begin{abstract}
Aiming to develop non-harmful and wide range efficient antibacterial agents, seven porphyrin derivatives, namely; 5,10,15,20-tetrapyridylphorphyrinato-Zn(II) (P1); 5, 10,15,20-tetra-(4-carboxy-phenyl)-porphyrin (P2); 5-(4-carboxyphenyl)10,15,20-triphenyl-porphyrin (P3); 5, 10,15,20-tetra-(3-hydroxy-phenyl)-porphyrin (P4); 5-(3-hydroxy-phenyl)-10,15,20-tris(3,4-dimethoxy-phenyl)-porphyrin (P5); 5-(4-carboxy-phenyl)-10,15,20-tris-(4-phenoxy-phenyl)-porphyrin (P6); 5,10,15,20tetrakis(pentafluorophenyl)-porphyrinato-Zn(II) (P7) in gold colloid solution in comparison with gold nanoparticles were tested using the diffusion method. The porphyrins that presented an inhibition zone diameter larger than $15 \mathrm{~mm}$, with proven antibacterial activity were selected and further tested by the dilution method to establish minimum inhibitory concentration (MIC) and minimum bactericidal concentration (MBC). Generating an inhibition zone diameter of only $7 \mathrm{~mm}$, the gold colloid per se does not fulfil the criteria as antimicrobial agent but we take into account that the porphyrin-gold hybrid/mixture might offer an enhancement of the biological activity even in non-illuminated media. All the porphyrin-bases present antibacterial activity against the nosocomial Gram-positive Staphylococcus aureus. All the porphyrins mesosubstituted to the phenyl ring with hydroxy- or carboxy-functional groups present a significant antimicrobial activity against Enterococcus faecalis. Zn-metalloporphyrins show a lower antibacterial efficiency compared to the porphyrin-bases. The best and wide antibacterial activity covering bacilli, cocci and fungi is provided by an $\mathrm{A}_{3} \mathrm{~B}$ mixed asymmetrically substituted molecule (P5), acting even at very low concentrations of $0.06 \mathrm{mg} / \mathrm{mL}$. Its significant bactericidal behaviour is probably due to its capacity to better penetrate the cell wall based on its amphiphilic character.
\end{abstract}

\section{Rezumat}

În scopul elaborării de noi agenți antibacterieni, netoxici și eficienți împotriva unei largi categorii de bacili, coci şi fungi, au fost testate prin metoda difuziunii șapte porfirine notate P1 - P7 în mediu de coloid de aur, precum și nanoparticulele de aur ca atare. Porfirinele cu activitate antibacteriană dovedită, care au prezentat un diametru al zonei de inhibiție mai mare de 15 $\mathrm{mm}$, au fost testate în continuare prin metoda diluțiilor pentru a fi determinate concentrația minimă inhibitorie (CMI) și concentrația minimă bactericidă (CMB). Coloidul de aur per se generează o zonă de inhibiție cu un diametru de $7 \mathrm{~mm}$, deci nu îndeplinește criteriile pentru un agent antimicrobian eficient, dar prezentul studiu pornește de la prezumpția ca hibridul porfirină-nanoaur poate oferi o îmbunătăţire a activității biologice chiar și în medii de cultură neexpuse la lumină. Toate porfirinele-bază prezintă o activitate antibacteriană certă față de bacteria nosocomială Gram-pozitivă Staphylococcus aureus. Toate porfirinele meso-substituite la inelul fenilic cu grupări hidroxil sau carboxil prezintă o activitate antibacteriană certă împotriva Enterococcus faecalis. Zn-metaloporfirinele prezintă o activitate antibacteriană mai slabă comparativ cu cea a porfirinelor-bază analizate. Cea mai bună eficiență antibacteriană împotriva cocilor, bacililor și fungilor o prezintă porfirina P5, de tip $\mathrm{A}_{3} \mathrm{~B}$, substituită asimetric. Aceasta acționează și la concentrații extrem de mici (diluții mari), iar comportamentul său bactericid poate fi explicat probabil prin capacitatea sa de a penetra mai ușor peretele celular datorită caracterului său am fifil.

Keywords: antibacterial activity, porphyrins, gold colloid, nosocomial bacteria, fungi

\section{Introduction}

The extensive use of antibiotics lead to the development of multi-drug resistant Gram-positive and negative bacteria like Pseudomonas aeruginosa, Enterococcus faecium, Staphylococcus aureus, Klebsiella pneumonia,
Escherichia coli (which were reported by WHO in 2017 as the greatest threat to human health) $[1,2]$, thus invoking an urgent necessity for the identification of new antimicrobial compounds. 
FARMACIA, 2020, Vol. 68, 2

Escherichia coli, Enterococcus faecalis and fungus Candida albicans are the organisms most frequently capable to form biofilms, considered as organized cellular structures. The biofilm forming bacteria exude to matrix protein-sugar polymers to create a barrier against antibiotics, which is a major concern for actual hospital environments. Au- and Ag-NPs are recommended for their capacity to inhibit bacteria and fungi biofilm growth.

$\mathrm{Au}$ - and Ag-nanoparticles manifest collective coherent oscillation with respect to the positive metallic lattice at a certain frequency of the light, so that each metal nanoparticle can develop optical properties equivalent to a million dye molecules. Another advantage is that metal nanoparticles are photo-stable and do not undergo photo-bleaching [3].

Another important issue is to differentiate between cytotoxicity and cellular damage [4] produced by $\mathrm{Au}-$ NPs function of their size, shape and concentration. A recent research [5] indicated that citrate-capped gold nanospheres $13 \mathrm{~nm}$ in diameter were not toxic for skin cells, but the particles led to decreases in cell proliferation, adhesion, and motility. Cytotoxicity also depends on the type of cells used.

Star-shaped AuNPs have been used in drug delivery systems directly to the tumour cell nucleus resulting in cell death [6]. The same authors established that the effect of $34 \mathrm{~nm}$ AuNPs on the proliferation of primary mouse keratinocytes in concentrations lower that 5 ppm increased the proliferation of cells, while high concentration induced toxic effect.

In order to design customized nanoparticles for cosmetic and transdermal drug delivery application, AuNPs of different sizes (2 - $5 \mathrm{~nm}$ ) and surface charges (cationic and anionic) were tested by molecular dynamics simulations on the model skin lipid membrane. The best permeability was attained by neutral $2 \mathrm{~nm}$ gold nanoparticle (AuNP) and the lowest for $3 \mathrm{~nm}$ cationic AuNP [7].

Larger functional gold nanoparticles that carried an ndecane end group was capable to inhibit Escherichia coli proliferation at only $32 \mathrm{nM}$ and was effective in treating methicillin-resistant Staphylococus aureus with minimum inhibitory concentration 8 - 64 nM [8]. Porphyrins are tetrapyrrolic macrocycles with amazing optical and chemical properties that also possess a high binding affinity to cellular components, membranes, proteins and DNA and this feature is a prerequisite for their biological activity.

Generally, it was reported that Gram-positive bacteria are efficiently inactivated by a large variety of porphyrins $[9,10]$, whereas Gram-negative bacteria only by cationic porphyrins $[11,12]$. Some porphyrins functionalized with amino groups [13] and cationic porphyrins were reported [14] to be highly active against both types of bacteria, because of a complex action that is beginning with the disruption of the bacterial cell wall followed by photosensitization.

These differences arise from the fact that Gram-positive species have their outer wall, located outside the cytoplasmic membrane and this has a porous structure [15]. Instead, Gram-negative bacteria have a higher thickness with 10 - $15 \mathrm{~nm}$ than the Gram-positive ones and a highly organized outer membrane, which inhibits the penetration of biologically active species [16]. Preserving monomerization is essential for achieving drug formulations of high bioavailability. Porphyrin aggregates might be inspected by UV-Vis spectroscopy due to generating blue shifted bands (H-aggregates) in the region beneath $400 \mathrm{~nm}$ or red-shifted bands in the $450-500 \mathrm{~nm}$ region assigned to J-type aggregates. J-aggregates are described as parallel planes of porphyrin caused by edge-to-edge stacking. H-aggregates generate stacked planes of porphyrin resulting from face-toface aggregation [17]. The main factors that influence aggregation are: increased porphyrin concentration, acidification [18] and reduced polarity of the environment [19], metal ions [20] and presence of surfactants [21]. In order to characterize antibacterial potential of the porphyrins and metalloporphyrins tested in this study, alone and in combinations, we used the agar diskdiffusion method, followed by Broth microdilutions method [22-25].

Although a great variety of antibacterial agents have been developed during last decades, they usually exhibit a low efficacy and/or major side-effects, raising a barrier to their clinical translation. Thus, there exists the urgent need to develop novel drugs enabling nonharmful and efficient therapeutic treatments against bacteria and fungi.

The aim of this study is to evaluate various porphyrin compounds as potential antibacterial agents.

These potential antibacterial agents should respect the main requirements: to be non-toxic to humans; to be effective without the need for light illumination and to perform activity both on Gram-positive and Gram-negative bacteria.

To accomplish these requirements the following symmetrical and asymmetrical meso-substituted porphyrins and $\mathrm{Zn}$-metalloporphyrins were used as potential antimicrobial agents: 5,10,15,20-tetrapyridylphorphyrinato-Zn(II) (P1); 5,10,15,20-tetra-(4-carboxyphenyl)-porphyrin (P2); 5-(4-carboxyphenyl)-10,15,20triphenyl-porphyrin (P3); 5,10,15,20-tetra-(3-hydroxyphenyl)-porphyrin (P4); 5-(3-hydroxy-phenyl)-10,15,20tris-(3,4-dimethoxy-phenyl)-porphyrin (P5); 5-(4carboxy-phenyl)-10,15,20-tris-(4-phenoxy-phenyl)porphyrin (P6); 5,10,15,20-tetrakis(pentafluorophenyl)porphyrinato- $\mathrm{Zn}(\mathrm{II})$ (P7). 

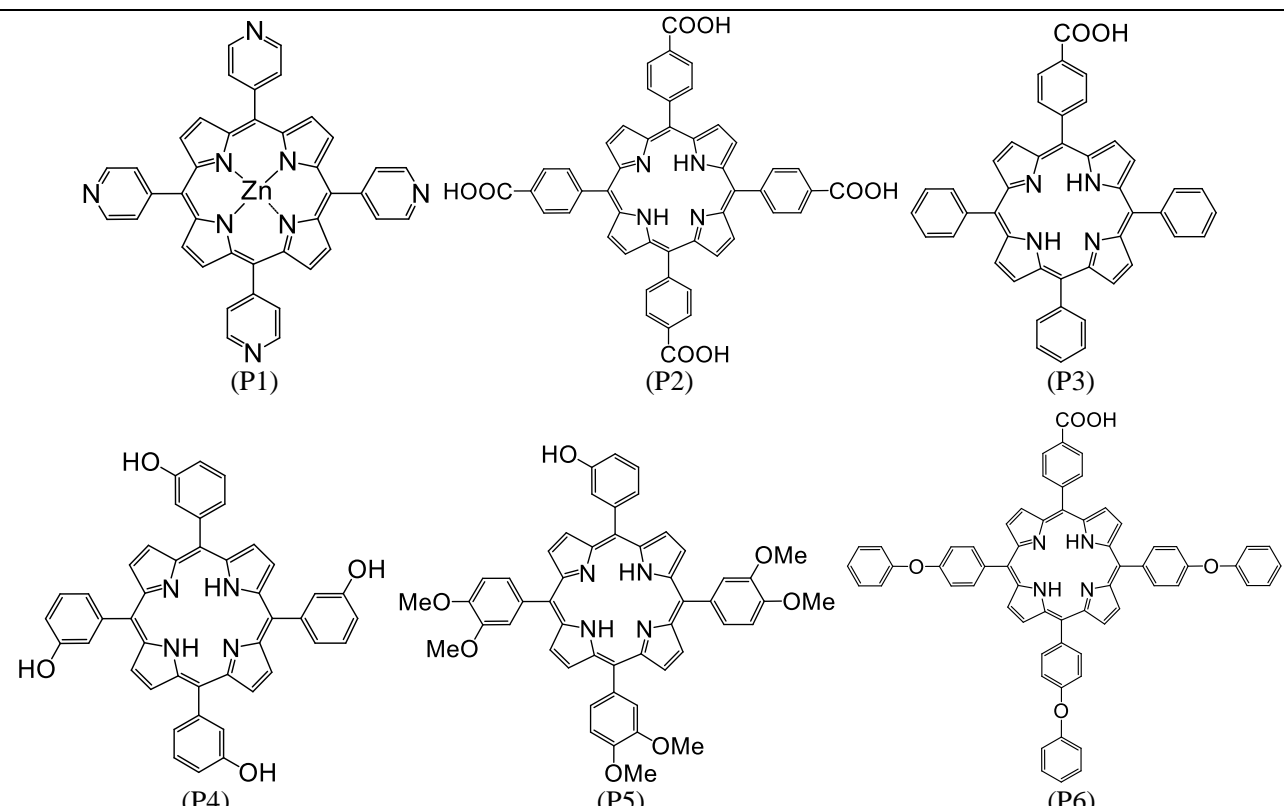

(P4)

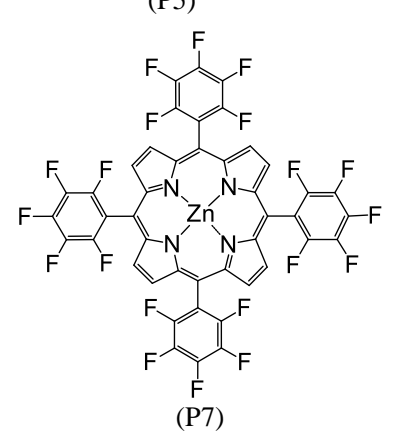

(P6)

Figure 1.

The chemical structures of the seven tested porphyrin derivatives

The evaluation of the antibacterial activity was performed both by the diffusion method and by the dilution method on a standardized subculture, with the determination of the minimum inhibitory concentration (MIC) and the minimum bactericidal concentration (MBC).

The reference bacterial strains used for the tests were selected such as to include various species: Grampositive cocci, Gram-negative bacilli, fungi strains: Staphylococcus aureus, Enterococcus faecalis, Salmonella enterica serotype typhimurium, Shigella flexneri serotype 2b, Escherichia coli, Klebsiella pneumoniae, Pseudomonas aeruginosa, Candida albicans and Candida parapsilosis.

\section{Materials and Methods}

Porphyrins were obtained in our laboratory as follows: the $\mathrm{A}_{3} \mathrm{~B}$ porphyrins $\mathrm{P} 3, \mathrm{P} 5, \mathrm{P} 6$ by multicomponent Adler-Longo synthesis [17, 26, 27]; the symmetrical P1, P2, P4 porphyrins by Adler method [28-30] and the 5,10,15,20-tetrakis(pentafluorophenyl)-porphyrinato$\mathrm{Zn}$ (II) (P7) was provided by Merck. The nanogold colloid solution was prepared using a previously published method [31-36] having an initial concentration of $4.58 \times 10^{-4} \mathrm{M}$ and the dilutions were performed according to biological requirements.

The following Gram-positive Staphylococcus aureus (ATCC25923), Enterococcus faecalis (ATCC51299), Gram-negative Salmonella enterica typmhimurium (ATCC14028), Shighella flexneri serotype $2 b$ (ATCC 12022), Klebsiella pneumonia (ATCC700603), Pseudomonas aeruginosa (ATCC27853) and Escherichia coli (ATCC25922) bacterial strains and two fungal strains Candida albicans (ATCC10231) and Candida parapsilosis (ATCC 22019) were acquired from ThermoScientific.

Diffusion method

The diffusion method, being more facile and less expensive, was used for the screening of the antibacterial activity of the tested substances.

Procedure and material preparation. The tested substance is deposited on the surface of a culture agar medium, previously inoculated with the tested bacterium. Two phenomena occur simultaneously: the diffusion of the antimicrobial substance in the medium and the proliferation of the bacterium. In the areas where the antimicrobial substance has a higher concentration than MIC no bacterial growth can be detected. The area of the inhibition zone is established 
early in the incubation period, as the geometric point of all the dots where the tested antimicrobial substance reached MIC at the critical moment of the culture. Thus, the area of the inhibition zone varies inversely with MIC [37, 38].

The composition and $\mathrm{pH}$ of the culture medium, the density of the inoculum, the stability and diffusion capacity of the antimicrobial substance, as well as the duration and temperature of incubation are among the variables that influence the results of the diffusion antimicrobial susceptibility tests.

The reference bacterial strains were developed in $10 \mathrm{~mL}$ glucose broth and then inoculated on agar Columbia $+5 \%$ sheep blood and the fungi on Sabouraud with chloramphenicol, with constant temperature of $37^{\circ} \mathrm{C}$ for 24 hours.

The density of the inoculum (the number of bacteria in contact with the tested substance) is a prerequisite for results reproducibility.

According to Clinical and Laboratory Standards Institute (CLSI) Standard, a bacterial suspension in sterile saline equivalent to $0.5 \mathrm{McF}$ arland $\left(10^{8} \mathrm{CFU} / \mathrm{mL}\right)$ is prepared. For the two Candida strains the density of the inoculum was $2 \mathrm{McF}$ arland.

As culture medium, Mueller-Hinton (BioMerieux, France) agar recommended by CLSI was used. This medium, that has an appropriate nutritional value, allows for the correct evaluation of a large variety of germs because it does not inhibit the antimicrobial action of the tested compounds. The gelose concentration was $1.5 \%-1.7 \%, \mathrm{pH}=7.2-7.4$ and the thickness of the culture medium on the Petri dishes was $4 \mathrm{~mm}$.

For the Candida strains a Mueller-Hinton medium was used, that was supplemented with methylene blue (Sanimed, Romania).

The control of the sterility of the culture media consisted in the incubation of a Petri dish from the batch for 24 hours at $37^{\circ} \mathrm{C}$.

Blank paper disk (BioMaxima, Poland) having $6 \mathrm{~mm}$ diameter were used.

The tested substances were prepared by pipetting $200 \mu \mathrm{L}$ nanogold over $200 \mathrm{mg}$ dry substance.

Other materials: sterile saline, cotton tampons on wood rods and clips were used for the deposition of paper disk.

The technique of disk-diffusion antibiotic resistance testing. The standardised bacterial suspension was obtained by suspending in the sterile saline of $2-3$ culture colonies for 24 hours on Columbia agar $+5 \%$ sheep blood. For the Candida strains the medium was Sabouraud with chloramphenicol.

The Petri dishes with the medium destined for antibiotic resistance testing were dried under controlled temperature for approximatively 20 minutes.

The inoculation was performed with a sterile, nontoxic cotton wool swab that was dipped in the bacterial suspension. The excess was removed by pressing against the tube walls. Then the medium was swabbed evenly in three directions. A marginal circular striation was performed in the end, in order to obtain a uniform inoculum.

After inoculation the dishes were left 5 - 10 minutes at room temperature to facilitate the absorption of the inoculum in the medium. Then microfilters were deposited $25 \mathrm{~mm}$ apart and $15 \mathrm{~mm}$ from the Petri dish edge. The tested substances were deposited as volumes of $10 \mu \mathrm{L}$ on each blank paper disk.

A single dish was used for each compound to be tested, containing the paper disk with the evaluated substance and two control paper disks. The positive control consists in a $10 \mu \mathrm{g}$ gentamicin disk (in the case of Enterococcus faecalis $120 \mu \mathrm{g}$ ). For the Candida strains the positive control was a $10 \mu \mathrm{g}$ fluconazole disk. As negative control a blank paper disk impregnated with only nanogold was used.

The Petri dishes prepared in this way were incubated for $24-48 \mathrm{~h}$ at $37^{\circ} \mathrm{C}$.

The interpretation of results was done after incubation, reading and recording the diameter of the zones of inhibition using a ruler. Duplicate tests were performed for all bacterial strains.

\section{Dilution method}

The dilution method allows for the MIC (minimum inhibitory concentration) and $\mathrm{MBC}$ (minimum bactericidal concentration) determination.

Protocol: increasing dilutions of the tested substances dissolved in liquid medium are prepared in separate test tubes. Then, fixed amounts of microbial cultures are added to each tube and are left to incubate for $24 \mathrm{~h}$ at $37^{\circ} \mathrm{C}$. The lowest concentration of the tested substance that inhibits bacterial growth is determined.

Procedure and materials preparations: sterile test tubes, liquid culture medium (Mueller-Hinton broth), tested compounds, microbial suspension 0.5 McFarland from reference strains, pipettes, thermostat. An inoculum is prepared from the $0.5 \mathrm{McFarland}$ bacterial suspension by dilution 1:150 in order to obtain a suspension of $10^{4} \mathrm{CFU} / \mathrm{mL}$ (colony-forming units $/ \mathrm{mL}$ ). A further dilution $1: 2$ brings the final inoculum to $5 \times 10^{5}$ CFU/mL [1].

The test was performed in 5 tubes as follows: in each tube $0.5 \mathrm{~mL}$ bacterial suspension $\left(5 \times 10^{5} \mathrm{CFU} / \mathrm{mL}\right)$ was pipetted, then $0.4 \mathrm{~mL}$ Mueller-Hinton broth and $0.1 \mathrm{~mL}$ of each diluted solution of the investigated substance $(200 \mu \mathrm{g}$ substance in nanogold/DMSO resulting the following dilutions $1 / 2 ; 1 / 4 ; 1 / 8 ; 1 / 16$; $1 / 32$ ). The total liquid volume was $1 \mathrm{~mL}$ that was finally homogenized. For each tested strain a positive control was used. This contained $0.5 \mathrm{~mL}$ bacterial suspension, $0.4 \mathrm{~mL}$ Mueller-Hinton broth and 0.1 $\mathrm{mL}$ nanogold $\left(1 \times 10^{-4} \mathrm{~mol} / \mathrm{L}\right)$. The negative control contained $0.1 \mathrm{~mL}$ compound and $0.4 \mathrm{~mL}$ Mueller Hinton broth and $0.5 \mathrm{~mL}$ nano-Au.

Interpretation: the first to be read is the control that has to be turbid (murky) (if the germs did grow). In case there is no bacterial growth, the broth in the 
control tube is clear and the test is invalid. If the control is proper, the procedure was performed correctly and the reading of the rest of the test tubes can proceed. The medium in the tubes containing the investigated substance is clearer than the control, and the smallest concentration of substance that inhibits bacterial growth (MIC) can be identified.

Determination of $M B C$ : a volume of $0.1 \mathrm{~mL}$ from each test tube, including control, was inoculated on Mueller-Hinton agar and on Columbia agar $=5 \%$ sheep blood or Sabouraud with chloramphenicol; the incubation was 24 hours at $37^{\circ} \mathrm{C}$; then the lowest concentration of substance at which the germs did not grow (MBC) was determined [1].

Solutions were made from a mixture containing $200 \mu \mathrm{g}$ porphyrin derivatives P1-P7 and $200 \mu \mathrm{L}$ nanogold colloid representing a concentration of $1 \mathrm{mg} / \mathrm{mL}$, and diluted to obtain the following dilutions: D $1 / 2$ (0.5 mg/mL); D 1/4 (0.25 mg/mL); D 1/8 (0.12 mg/mL); D $1 / 16(0.06 \mathrm{mg} / \mathrm{mL}) ; \mathrm{D} 1 / 32(0.03 \mathrm{mg} / \mathrm{mL})$. Reagents

The used solvents and reagents of the highest purity (THF, DMF, chloroform, benzonitrile, DMSO) were purchased from Merck and Aldrich.

\section{Apparatus}

Spectrophotometric measurements were investigated on a JASCO model V-650 spectrometer using $1 \mathrm{~cm}$ wide quartz cuvettes. Fluorescence spectra were recorded on a PERKIN ELMER Model LS 55 apparatus in a $1 \mathrm{~cm}$ cuvette. STEM images were registered using a Titan G2 80-200 TEM/STEM microscope (FEI Comp., The Netherlands). Samples were prepared by dropcasting the gold and porphyrin derivatives from water and benzonitrile on 200 mesh TEM copper grids coated with continuous carbon film. The images were registered at $200 \mathrm{kV}$ using TEM Imaging \& Analysis v. 4.7 software.

\section{Results and Discussion}

The absorption spectra of all studied porphyrinbases comprise the $\left(\pi-\pi^{*}\right)$ absorption bands that are characteristic for all etio type porphyrins showing an intense Soret band around $420 \mathrm{~nm}$ and a slight shoulder at higher energy, around $400 \mathrm{~nm}$, due to $\mathrm{B}(0,0)$ and $\mathrm{B}(0,1)$ electronic transitions, respectively. The four $\mathrm{Q}$ bands (of weaker intensity) in the visible spectral region are located around 510, 550, 590 and $650 \mathrm{~nm}$ (as presented in Table I and Figure 2). In diluted THF or $\mathrm{CHCl}_{3}$ or $\mathrm{CH}_{2} \mathrm{Cl}_{2}$ solution at neutral $\mathrm{pH}$ each spectrum was typical for monomeric porphyrins.

Table I

The main absorption and emission band in UV-Vis and fluorescence spectra of the seven porphyrins

\begin{tabular}{|c|c|c|c|c|c|c|c|c|c|}
\hline \multicolumn{8}{|c|}{ UV-Vis absorption bands [nm] } & \multicolumn{2}{|c|}{ Emission maxima [nm] in THF } \\
\hline Porphyrin samples & Soret & $\mathbf{Q}_{\text {IV }}$ & $\mathbf{Q}_{\text {III }}$ & $\mathbf{Q}_{\mathrm{II}}$ & $\mathbf{Q}_{\mathrm{I}}$ & $\begin{array}{l}\text { Log } \varepsilon \text { for } \\
\text { Soret band }\end{array}$ & Solvent & $\mathbf{Q}_{\mathrm{x}}(\mathbf{0 , 0})$ & $\mathbf{Q}_{\mathbf{x}}(\mathbf{0 , 1})$ \\
\hline $\begin{array}{l}5,10,15,20 \text {-tetra-pyridyl- } \\
\text { porphyrinato-Zn(II) (P1) }\end{array}$ & 422 & & 555 & & 594 & 5.681 & THF & $602 /$ due to $\mathrm{Zn} 651$ & \\
\hline $\begin{array}{l}\text { 5,10,15,20-tetra-(4-(carboxy- } \\
\text { phenyl)-porphyrin }(\mathrm{P} 2)\end{array}$ & 419 & 515 & 549 & 590 & 646 & 5.310 & DMF & 655 & 717 \\
\hline $\begin{array}{l}\text { 5-(4-carboxy-phenyl)-10,15,20- } \\
\text { triphenyl-porphyrin (P3) }\end{array}$ & 417 & 513 & 47 & 590 & 647 & 5.284 & THF & 654 & 718 \\
\hline $\begin{array}{l}\text { 5,10,15,20-tetra-(3-hydroxy- } \\
\text { phenyl)-porphyrin (P4) }\end{array}$ & 420 & 515 & 549 & 590 & 648 & 5.453 & $\mathrm{CHCl}_{3}$ & 655 & 717 \\
\hline $\begin{array}{c}\text { 5-(3-hydroxy-phenyl)-10,15,20- } \\
\text { tris-(3,4-dimethoxy-phenyl)- } \\
\text { porphyrin (P5) }\end{array}$ & 423 & 518 & 555 & 592 & 650 & 5.041 & THF & 655 & 713 \\
\hline $\begin{array}{c}\text { 5-(4-carboxy-phenyl)-10,15,20- } \\
\text { tris-(4-phenoxy-phenyl)- } \\
\text { porphyrin (P6) }\end{array}$ & 420 & 515 & 550 & 592 & 650 & 5.240 & THF & 657 & 721 \\
\hline $\begin{array}{l}\text { 5,10,15,20-tetrakis(pentafluoro- } \\
\text { phenyl)-porphyrinato-Zn(II) (P7) }\end{array}$ & 420 & & 551 & & 626 & 5.352 & DMF & 586/due to $\mathrm{Zn} 632$ & \\
\hline
\end{tabular}




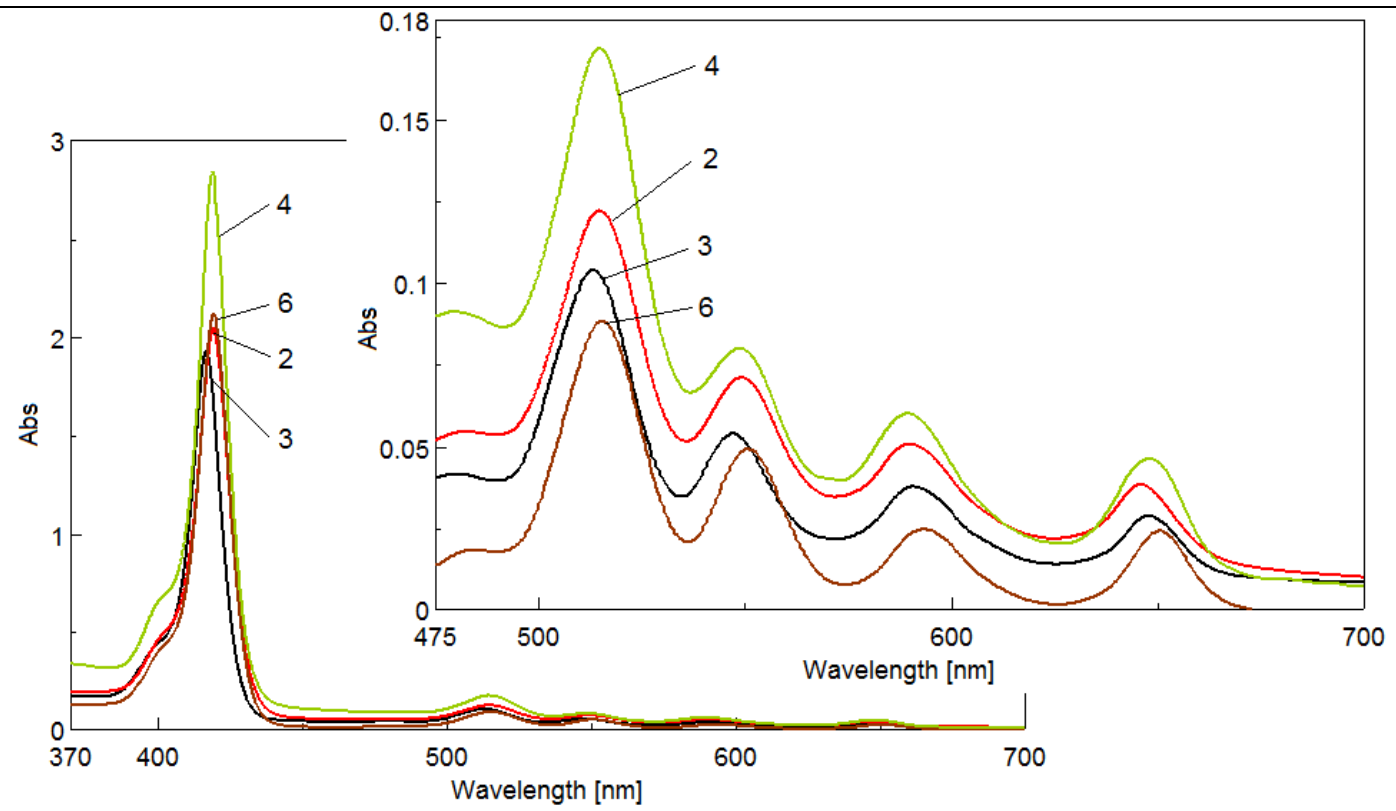

Figure 2.

Viscosity curves and the statistical mean of differences expressed by the regression lines $(2=\mathrm{P}(2) ; 3=\mathrm{P}(3) ; 4=\mathrm{P}(4) ; 6=\mathrm{P}(6))$

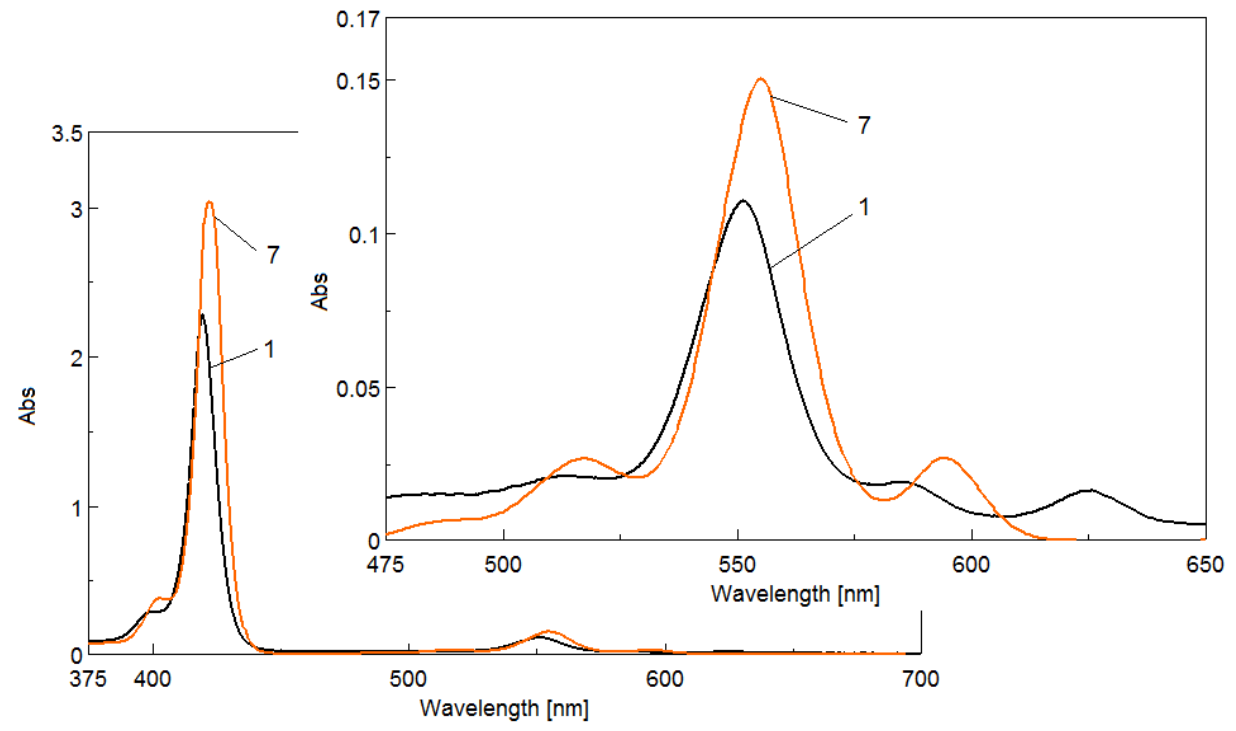

Figure 3.

The overlapped spectra of the two Zn-metalloporphyrins $(1=\mathrm{P}(1) ; 7=\mathrm{P}(7))$

As expected, the two Zn(II)-porphyrins have a diminished number of $Q$ bands due to increasing in symmetry from $\mathrm{D}_{2 \mathrm{~h}}$ in free base-porphyrins to $\mathrm{D}_{4 \mathrm{~h}}$ in symmetrical Zn(II)-metalloporphyrins: Zn(II)-5,10, 15,20-tetrakis-(pentafluorophenyl)-porphyrin and 5, 10,15,20-tetra-pyridyl-porphyrinato-Zn(II) (Figure 3). The emission spectra of bare porphyrins (Figure 4) exhibited two maxima, a strong and broad $\mathrm{Q}_{\mathrm{x}}(0,0)$ fluorescence band shifting around $655 \mathrm{~nm}$ and a weaker emission band situated in the range 712 $720 \mathrm{~nm}$, assigned to $\mathrm{Q}_{\mathrm{x}}(0,1)$ transition. These two bands are mirror symmetric with the absorption bands QI and QII. This fluorescence behaviour justifies the inclusion of these porphyrins in the second generation of photosensitizers for PDT treatments $(\lambda>630 \mathrm{~nm}$ ), allowing the use of lower laser irradiation energy [39].

The Zn-metalloporphyrins also give two signals of lower intensity, the first located around $585-600 \mathrm{~nm}$ due to the influence of metal and the second band around 630 - $650 \mathrm{~nm}$, due to tetrapyrrolic macrocycle hypochromically shifted in comparison with porphyrin bases.

Differences between one of the Zn-porphyrin (curve 1) derivatives and one of the free base porphyrin (curve 2) emission spectrum are represented in Figure 4. 
The intensity of emission of the free-porphyrin is higher than that of the Zn-metalloporphyrin. The fluorescence band located around $650 \mathrm{~nm}$ in case of porphyrin-base is significantly hypsochromically shifted to $630 \mathrm{~nm}$ due to the presence of the strong electron withdrawing effect of the twenty fluorine atoms and a novel band around $585 \mathrm{~nm}$ is caused by the metal insertion.

The antibacterial activity testing of the seven porphyrin derivatives in colloidal gold environment and of gold colloid solution alone was firstly performed by the diffusion method. The reference bacterial strains used for the tests were selected such as to include various species: Gram-positive cocci, Gram-negative bacilli, fungi strains and the results are presented in Table II. Taking advantage of the ability of functionalized porphyrin-nano-metal hybrids [31-36] to shift the UV-Vis excitation wavelength towards near infrared regions (NIR), the development of these nanocomposites will also be addressed. That is the reason why we prepare our porphyrin solutions into diluted nanogold colloid, although it was proven to be inactive for all the biological performed tests, but the porphyrin- gold hybrid/mixture might offer a better biological activity.

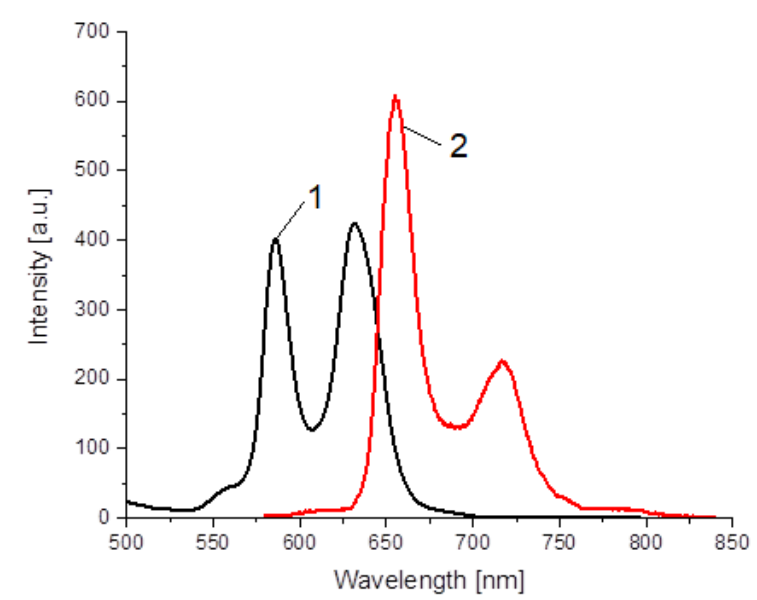

Figure 4.

Overlapped fluorescence spectra for 5,10,15,20tetrakis(pentafluoro-phenyl)-porphyrinato-Zn(II) (line 1) and 5,10,15,20-tetra-(4-(carboxy-phenyl)porphyrin (line 2)

\begin{tabular}{|c|c|c|c|c|c|c|c|c|c|}
\hline \multirow[b]{2}{*}{ 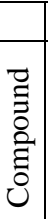 } & \multicolumn{5}{|c|}{ Gram-negative bacteria } & \multicolumn{2}{|c|}{ Gram-positive bacteria } & \multicolumn{2}{|c|}{ Fungi } \\
\hline & $\begin{array}{c}\text { Klebsiella } \\
\text { pneumoniae } \\
\text { (ATCC } \\
700603)\end{array}$ & \begin{tabular}{|c} 
Shigella \\
flexneri \\
(ATCC \\
12022 )
\end{tabular} & 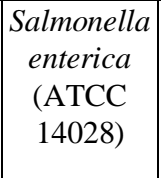 & $\begin{array}{c}\text { Escherichia } \\
\text { coli } \\
\text { (ATCC } \\
25922 \text { ) }\end{array}$ & $\begin{array}{c}\text { Pseudomonas } \\
\text { aeruginosa } \\
\text { (ATCC } \\
27853 \text { ) }\end{array}$ & $\begin{array}{c}\text { Staphylococcus } \\
\text { aureus } \\
\text { (ATCC } \\
225923 \text { ) }\end{array}$ & $\begin{array}{c}\text { Enterococcus } \\
\text { faecalis } \\
\text { (ATCC } \\
51299 \text { ) }\end{array}$ & \begin{tabular}{|c|}
$\begin{array}{c}\text { Candida } \\
\text { albicans } \\
\text { (ATCC } \\
10231)\end{array}$ \\
\end{tabular} & \begin{tabular}{|c|} 
Candida \\
parapsilosis \\
(ATCC \\
22019 )
\end{tabular} \\
\hline P1 & $9 \mathrm{~mm}$ & $9 \mathrm{~mm}$ & $9 \mathrm{~mm}$ & $9 \mathrm{~mm}$ & $7 \mathrm{~mm}$ & $12 \mathrm{~mm}$ & $11 \mathrm{~mm}$ & $9 \mathrm{~mm}$ & $9 \mathrm{~mm}$ \\
\hline $\mathrm{P} 2$ & $9 \mathrm{~mm}$ & $9 \mathrm{~mm}$ & $9 \mathrm{~mm}$ & $9 \mathrm{~mm}$ & $9 \mathrm{~mm}$ & $22 \mathrm{~mm}$ & $19 \mathrm{~mm}$ & $19 \mathrm{~mm}$ & $19 \mathrm{~mm}$ \\
\hline $\mathrm{P} 3$ & $16 \mathrm{~mm}$ & $16 \mathrm{~mm}$ & $16 \mathrm{~mm}$ & $19 \mathrm{~mm}$ & $16 \mathrm{~mm}$ & $19 \mathrm{~mm}$ & $18 \mathrm{~mm}$ & $16 \mathrm{~mm}$ & $16 \mathrm{~mm}$ \\
\hline $\mathrm{P} 4$ & $16 \mathrm{~mm}$ & $16 \mathrm{~mm}$ & $16 \mathrm{~mm}$ & $19 \mathrm{~mm}$ & $16 \mathrm{~mm}$ & $19 \mathrm{~mm}$ & $18 \mathrm{~mm}$ & $16 \mathrm{~mm}$ & $16 \mathrm{~mm}$ \\
\hline P5 & $17 \mathrm{~mm}$ & $17 \mathrm{~mm}$ & $17 \mathrm{~mm}$ & $18 \mathrm{~mm}$ & $18 \mathrm{~mm}$ & $22 \mathrm{~mm}$ & $23 \mathrm{~mm}$ & $25 \mathrm{~mm}$ & $22 \mathrm{~mm}$ \\
\hline P6 & $16 \mathrm{~mm}$ & $16 \mathrm{~mm}$ & $16 \mathrm{~mm}$ & $19 \mathrm{~mm}$ & $16 \mathrm{~mm}$ & $19 \mathrm{~mm}$ & $18 \mathrm{~mm}$ & $16 \mathrm{~mm}$ & $16 \mathrm{~mm}$ \\
\hline P7 & $16 \mathrm{~mm}$ & $16 \mathrm{~mm}$ & $16 \mathrm{~mm}$ & $19 \mathrm{~mm}$ & $16 \mathrm{~mm}$ & $19 \mathrm{~mm}$ & $18 \mathrm{~mm}$ & $16 \mathrm{~mm}$ & $16 \mathrm{~mm}$ \\
\hline $\begin{array}{l}\mathrm{n}- \\
\mathrm{Au}\end{array}$ & $7 \mathrm{~mm}$ & $7 \mathrm{~mm}$ & $7 \mathrm{~mm}$ & $7 \mathrm{~mm}$ & $7 \mathrm{~mm}$ & $7 \mathrm{~mm}$ & $7 \mathrm{~mm}$ & $7 \mathrm{~mm}$ & $7 \mathrm{~mm}$ \\
\hline
\end{tabular}

The compounds that exhibited an inhibition area larger than $15 \mathrm{~mm}$ (inhibition produced by the positive control gentamicin) were considered as having antibacterial activity and were further tested by the dilution method.

A correlation is observed between the inhibition zone diameter obtained by diffusion method (Table II) and MIC and MBC determined by dilution method (Table III). The larger the dilution of the investigated substance, the higher antibacterial activity can be observed.

The compounds P2, P3, P4, P5, P6 and P7 that presented an inhibition zone diameter larger than 15 $\mathrm{mm}$ (inhibition generated by the positive control gentamycin) were considered as possessing antimicrobial activity and were further tested by dilution method. Minimum inhibitory concentration (MIC) and minimum bactericidal concentration (MBC) were established.

It is considered that a substance does not present antibacterial activity, it is inactive, when the diameter of the inhibition zone is in the $7 \mathrm{~mm}-9 \mathrm{~mm}$ range; a poor activity exhibits when the diameter ranges from $10 \mathrm{~mm}$ to $14 \mathrm{~mm}$; a moderate antimicrobial activity is considered when the diameter ranges from $15 \mathrm{~mm}$ to $18 \mathrm{~mm}$ and if the diameter exceeds $18 \mathrm{~mm}$ the compound is considered to have a significant antimicrobial activity. 
Table III

Antibacterial activity tests using the dilution method

\begin{tabular}{|c|c|c|c|c|c|c|c|c|c|}
\hline & $\begin{array}{c}\text { Klebsiella } \\
\text { pneumoniae }\end{array}$ & $\begin{array}{l}\text { Shigella } \\
\text { flexneri }\end{array}$ & $\begin{array}{c}\text { Salmonella } \\
\text { enterica } \\
\end{array}$ & $\begin{array}{c}\text { Escherichia } \\
\text { coli } \\
\end{array}$ & $\begin{array}{c}\text { Pseudomonas } \\
\text { aeruginosa }\end{array}$ & $\begin{array}{c}\text { Staphylococcus } \\
\text { aureus }\end{array}$ & \begin{tabular}{|c|}
$\begin{array}{c}\text { Enterococcus } \\
\text { faecalis }\end{array}$ \\
\end{tabular} & $\begin{array}{l}\text { Candida } \\
\text { albicans }\end{array}$ & $\begin{array}{c}\text { Candida } \\
\text { parapsilosis }\end{array}$ \\
\hline P1 & & & & & & & & & \\
\hline $\mathrm{P} 2$ & & & & & & $\begin{array}{l}\text { CMI D1/16 } \\
\text { CMB D1/16 }\end{array}$ & $\begin{array}{l}\text { CMI D1/16 } \\
\text { CMB D1/16 }\end{array}$ & $\begin{array}{l}\text { CMI D1/4 } \\
\text { CMB D1/4 }\end{array}$ & $\begin{array}{c}\text { CMI D1/4 } \\
\text { CMB D1/4 }\end{array}$ \\
\hline P3 & $\begin{array}{l}\text { CMI D1/4 } \\
\text { CMB D1/2 }\end{array}$ & $\begin{array}{l}\text { CMI D1/4 } \\
\text { CMB D1/2 }\end{array}$ & $\begin{array}{l}\text { CMI D1/4 } \\
\text { CMB D1/2 }\end{array}$ & $\begin{array}{l}\text { CMI D1/4 } \\
\text { CMB D1/2 }\end{array}$ & $\begin{array}{l}\text { CMI D1/2 } \\
\text { CMB D1/2 }\end{array}$ & $\begin{array}{c}\text { CMI D1/4 } \\
\text { CMB D1/4 }\end{array}$ & & $\begin{array}{l}\text { CMI D1/4 } \\
\text { CMB D1/4 }\end{array}$ & $\begin{array}{c}\text { CMI D1/4 } \\
\text { CMB D1/4 }\end{array}$ \\
\hline P4 & $\begin{array}{c}\text { CMI D1/4 } \\
\text { CMB D1/2 }\end{array}$ & $\begin{array}{l}\text { CMI D1/4 } \\
\text { CMB D1/2 } \\
\end{array}$ & $\begin{array}{l}\text { CMI D1/4 } \\
\text { CMB D1/2 } \\
\end{array}$ & $\begin{array}{c}\text { CMI D1/4 } \\
\text { CMB D1/2 }\end{array}$ & $\begin{array}{c}\text { CMI D1/2 } \\
\text { CMB D1/2 }\end{array}$ & $\begin{array}{c}\text { CMI D1/4 } \\
\text { CMB D1/4 }\end{array}$ & $\begin{array}{c}\text { CMI D1/4 } \\
\text { CMB D1/4 }\end{array}$ & $\begin{array}{l}\text { CMI D1/4 } \\
\text { CMB D1/4 }\end{array}$ & $\begin{array}{c}\text { CMI D1/4 } \\
\text { CMB D1/4 }\end{array}$ \\
\hline P5 & $\begin{array}{l}\text { CMI D1/4 } \\
\text { CMB D1/4 }\end{array}$ & $\begin{array}{l}\text { CMI D1/4 } \\
\text { CMB D1/4 }\end{array}$ & $\begin{array}{c}\text { CMI D1/4 } \\
\text { CMB D1/4 }\end{array}$ & $\begin{array}{l}\text { CMI D1/4 } \\
\text { CMB D1/4 }\end{array}$ & $\begin{array}{c}\text { CMI D1/4 } \\
\text { CMB D1/4 }\end{array}$ & $\begin{array}{l}\text { CMI D1/8 } \\
\text { CMB D1/4 }\end{array}$ & $\begin{array}{l}\text { CMI D1/16 } \\
\text { CMB D1/8 }\end{array}$ & $\begin{array}{l}\text { CMI D1/16 } \\
\text { CMB D1/8 }\end{array}$ & $\begin{array}{l}\text { CMI D1/16 } \\
\text { CMB D1/8 }\end{array}$ \\
\hline P6 & $\begin{array}{l}\text { CMI D1/4 } \\
\text { CMB D1/4 }\end{array}$ & $\begin{array}{l}\text { CMI D1/4 } \\
\text { CMB D1/4 }\end{array}$ & $\begin{array}{c}\text { CMI D1/4 } \\
\text { CMB D1/4 } \\
\end{array}$ & $\begin{array}{l}\text { CMI D1/4 } \\
\text { CMB D1/4 }\end{array}$ & $\begin{array}{l}\text { CMI D1/4 } \\
\text { CMB D1/4 }\end{array}$ & $\begin{array}{l}\text { CMI D1/8 } \\
\text { CMB D1/4 }\end{array}$ & $\begin{array}{l}\text { CMI D1/8 } \\
\text { CMB D1/4 }\end{array}$ & $\begin{array}{l}\text { CMI D1/8 } \\
\text { CMB D1/4 }\end{array}$ & $\begin{array}{l}\text { CMI D1/8 } \\
\text { CMB D1/4 }\end{array}$ \\
\hline P7 & $\begin{array}{l}\text { CMI D1/4 } \\
\text { CMB D1/2 }\end{array}$ & $\begin{array}{l}\text { CMI D1/4 } \\
\text { CMB D1/2 }\end{array}$ & \begin{tabular}{|l|} 
CMI D1/4 \\
CMB D1/2
\end{tabular} & $\begin{array}{l}\text { CMI D1/4 } \\
\text { CMB D1/2 }\end{array}$ & $\begin{array}{l}\text { CMI D1/2 } \\
\text { CMB D1/2 }\end{array}$ & $\begin{array}{l}\text { CMI D1/4 } \\
\text { CMB D1/4 }\end{array}$ & $\begin{array}{l}\text { CMI D1/4 } \\
\text { CMB D1/4 }\end{array}$ & $\begin{array}{l}\text { CMI D1/4 } \\
\text { CMB D1/4 }\end{array}$ & $\begin{array}{l}\text { CMI D1/4 } \\
\text { CMB D1/4 }\end{array}$ \\
\hline
\end{tabular}

Porphyrins P1 and P2, namely: Zn(II)-tetra-pyridyl porphyrin and tetrakis-4-carboxyphenyl-porphyrin respectively, presenting an inhibition diameter in the $7 \mathrm{~mm}$ and $9 \mathrm{~mm}$ range, are inactive against all tested Gram-negative reference strains. Porphyrin P1 is also inactive against fungi (Candida albicans and Candida parapsilosis), presenting an inhibition diameter of 9 $\mathrm{mm}$ but has a weak antibacterial activity against Gram-positive bacterial strains Staphylococcus aureus and Enterococcus faecalis, (inhibition diameters of $12 \mathrm{~mm}$ and $11 \mathrm{~mm}$ respectively). Porphyrin P2 has an obvious antibacterial activity against Gram-positive cocci and against fungi, the inhibition diameters being larger than $18 \mathrm{~mm}$ (22 mm for the case of Staphylococcus aureus and $19 \mathrm{~mm}$ for Enterococcus faecalis, Candida albicans and Candida parapsilosis).

The porphyrins P4, P5, P6 and P7 presented a moderate activity against Gram-negative bacilli Klebsiella pneumoniae, Shigella flexneri, Salmonella enterica

and Pseudomonas aeruginosa, developing an inhibition zone with the diameter in the range $16 \mathrm{~mm}-18 \mathrm{~mm}$, but against Escherichia coli the antibacterial activity was significant, the inhibition zone measuring $19 \mathrm{~mm}$. Except for P1, all the other porphyrins present an obvious antibacterial activity against the Gram-positive $S$ aureus, developing an inhibition zone of $19-22 \mathrm{~mm}$. Comparing the antibacterial efficiency of the $\mathrm{Zn}$ metalloporphyrins with the porphyrin-bases it can be concluded that, in our environmental conditions, the presence of metal does not significantly influence the capacity to fight against both bacteria and fungi. The porphyrins P2 and P5 present a significant antimicrobial activity against Enterococcus faecalis with an inhibition zone of $23 \mathrm{~mm}$, instead the bactericidal activity of porphyrins P3, P4, P6 and P7 is moderate.

Generating an inhibition zone diameter of only $7 \mathrm{~mm}$, the gold colloid per se does not fulfil the criteria as antimicrobial agent.

Table IV

Antibacterial activity of porphyrins against reference strains

\begin{tabular}{|c|c|c|c|c|c|c|c|c|c|}
\hline Compound & $\begin{array}{c}\boldsymbol{K} . \\
\text { pneumoniae }\end{array}$ & $\begin{array}{c}\boldsymbol{S} . \\
\text { flexneri }\end{array}$ & $\begin{array}{c}\boldsymbol{S} . \\
\text { enterica }\end{array}$ & E. coli & $\begin{array}{c}\boldsymbol{P} . \\
\text { aeruginosa }\end{array}$ & S. aureus & $\begin{array}{c}\boldsymbol{E} . \\
\text { faecalis }\end{array}$ & $\begin{array}{c}\boldsymbol{C} . \\
\text { albicans }\end{array}$ & $\begin{array}{c}\boldsymbol{C} . \\
\text { parapsilosis }\end{array}$ \\
\hline P1 & inactive & inactive & inactive & inactive & inactive & weak & weak & inactive & inactive \\
\hline P2 & inactive & inactive & inactive & inactive & inactive & $\begin{array}{c}\text { Obvious } \\
\text { (strong) }\end{array}$ & obvious & obvious & obvious \\
\hline P3 & moderate & moderate & moderate & obvious & moderate & obvious & moderate & moderate & moderate \\
\hline P4 & moderate & moderate & moderate & obvious & moderate & obvious & moderate & moderate & moderate \\
\hline P5 & moderate & moderate & moderate & obvious & moderate & obvious & obvious & obvious & obvious \\
\hline P6 & moderate & moderate & moderate & obvious & moderate & obvious & moderate & moderate & moderate \\
\hline P7 & moderate & moderate & moderate & obvious & moderate & obvious & moderate & moderate & moderate \\
\hline nano-Au & inactive & inactive & inactive & inactive & inactive & inactive & inactive & inactive & inactive \\
\hline
\end{tabular}

Mixed asymmetrically substituted P5 porphyrin, as a representative of Second generation sensitizers, is characterized by improved photo-physical properties capable to reduce skin photosensitivity and to increase quantum yields $\left(\Phi_{\mathrm{f}}=0.148 \pm 0.011\right)$ and is able to be distorted in saddle type architecture and to generate by aggregation biomorphic structures (Figures 5a and 5b) [27]. The so-called amphiphilic molecules, since porphyrin ring is hydrophobic, are able to better penetrate the cell wall justifying its significant antibacterial activity. Contrary to our expectation, gold colloid solution alone does not present antibacterial activity, probably due to a strong tendency to aggregate in long chains (Figure 5c). 
FARMACIA, 2020, Vol. 68, 2
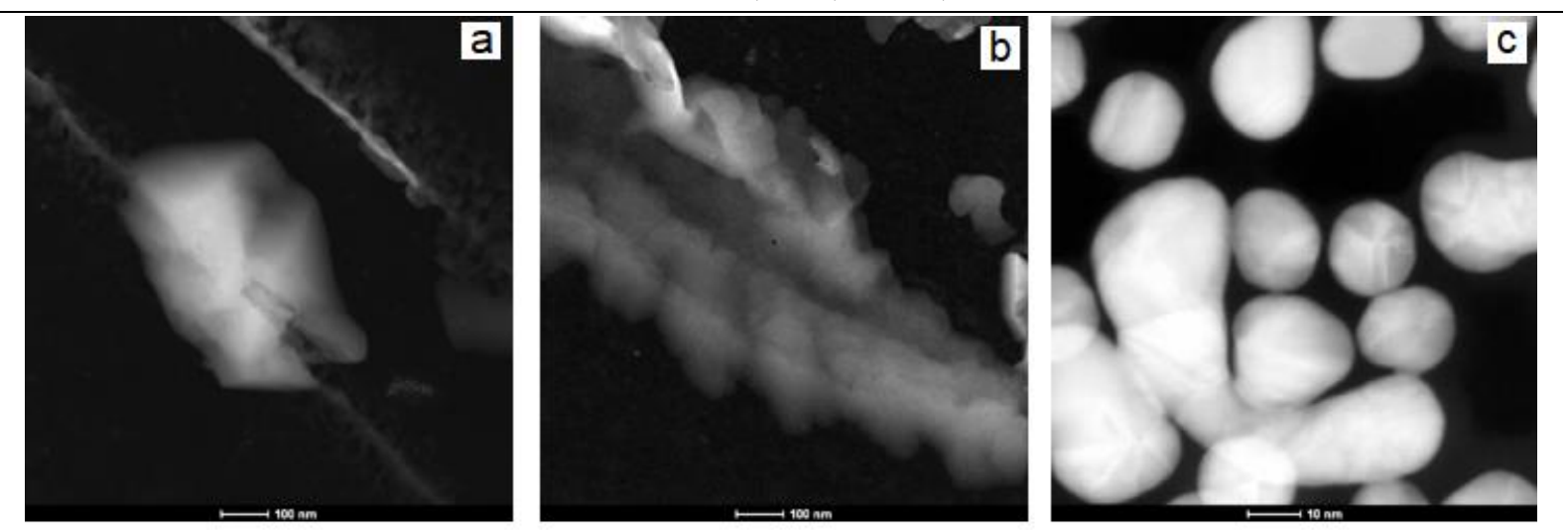

Figure 5.

STEM image of the P5 porphyrin from benzonitrile solution and of gold colloid solution from water

\section{Conclusions}

The antibacterial activity testing of the seven porphyrin derivatives in colloidal gold solution and of gold colloid solution alone was performed by the diffusion method. The compounds P2, P3, P4, P5, P6 and P7 that presented an inhibition zone diameter larger than 15 $\mathrm{mm}$ were considered as having antibacterial activity and were further tested by the dilution method, for the establishing of MIC and MBC. Generating an inhibition zone diameter of only $7 \mathrm{~mm}$, the gold colloid per se does not fulfil the criteria as antimicrobial agent probably due to a strong tendency to aggregate in long chains, as proven by STEM analysis.

Porphyrins P1 and P2 are inactive against all tested Gram-negative reference strains. Zn-metalloporphyrin P1 is also inactive against fungi, but has a weak antibacterial activity against Gram-positive bacterial strains. Nevertheless, porphyrin P2 has an obvious antibacterial activity against Gram-positive cocci and against fungi, the inhibition diameters being larger than $18 \mathrm{~mm}$ (22 $\mathrm{mm}$ for the case of Staphylococcus aureus and $19 \mathrm{~mm}$ for Enterococcus faecalis, Candida albicans and Candida parapsilosis).

The porphyrins P3, P4, P5, P6 and P7 presented a moderate activity against Gram-negative bacilli providing exceptional results against Escherichia coli.

A remarkable result is that, excepting P1, all the other porphyrins present an obvious antibacterial activity against multi-drug resistant Gram-positive $S$. aureus. The porphyrins P2 and P5 present an obvious antimicrobial activity against another nosocomial bacteria Enterococcus faecalis with an inhibition zone more prominent than that of P3, P4, P6 and P7.

Zn-metalloporphyrins show a lower antibacterial efficiency compared to the porphyrin-bases in our environmental conditions, proving that the presence of metal does not significantly influence the capacity to fight against both bacteria and fungi.

The best antibacterial activity covering bacilli, cocci and fungi is provided by an $\mathrm{A}_{3} \mathrm{~B}$ mixed asymmetrically substituted amphiphilic molecule (P5) that is probably more capable to better penetrate the cell wall justifying in this way its significant bactericidal behaviour.

\section{Acknowledgement}

All authors are kindly acknowledging the support received from "Victor Babeș" University of Medicine and Pharmacy, Timișoara, Romania, Department of Microbiology and Virusology. The authors from Institute of Chemistry Timişoara of Romanian Academy are grateful to Programme 3 - 2018.

\section{Conflict of interest}

The authors declare no conflict of interest.

\section{References}

1. Mayers DL, Sobel JD, Ouelette M, Kaye KS, Marchaim D, Antimicrobial Drug Resistance: Clinical and Epidemiological Aspects, vol.2, $2^{\text {nd }}$ Edition, Springer Cham, Switzerland, 2017; 777-1598.

2. Bayrak N, A new family of azanaphthoquinones for antimicrobial evaluation. Chem Cent J., 2018; 12(1): 21: 1-9.

3. Jain PK, Huang X, El-Sayed IH, El-Sayed MA, Noble metals on the nanoscale: Optical and photothermal properties and some applications in imaging, sensing, biology, and medicine. Acc Chem Res., 2008; 41(12): 1578-1586.

4. Johnston HJ, Hutchison G, Christensen FM, Peters S, Hankin S, Stone V, A review of the in vivo and in vitro toxicity of silver and gold particulates: Particle attributes and biological mechanisms responsible for the observed toxicity. Crit Rev Toxicol., 2010; 40(4): 328-346.

5. Murphy CJ, Gole AM, Stone JW, Sisco PN, Alkilany AM, Goldsmith EC, Baxter SC, Gold nanoparticles in biology: Beyond toxicity to cellular imaging. Acc Chem Res., 2008; 41(12): 1721-1730.

6. Niska K, Zielinska E, Radomski MW, InkielewiczStepniak I, Metal nanoparticles in dermatology and cosmetology: Interactions with human skin cells. Chem Biol Interact., 2017; 1-14.

7. Gupta R, Rai B, Effect of size and surface charge of gold nanoparticles on their skin permeability: A 
FARMACIA, 2020, Vol. 68, 2

molecular dynamics Study. Sci Rep., 2017; 7: 45292: 1-13.

8. Li X, Robinson SM, Gupta A, Saha K, Jiang Z, Moyano DF, Sahar A, Riley MA, Rotello VM, Functional gold nanoparticles as potent antimicrobial agents against multi-drug-resistant bacteria. ACS Nano, 2014; 8(10): 10682-10686.

9. Merchat M, Bertoloni G, Giacomini P, Villanueva A, Jori G, Meso-substituted cationic porphyrins as efficient photosensitizers of Gram-positive and Gramnegative bacteria. J Photochem Photobiol. B, 1996; 32(3): 153-157.

10. Ashkenazi H, Nitzan Y, Gal D, Photodynamic effects of antioxidant substituted porphyrin photosensitizers on Gram-positive and Gram-negative bacteria. Photochem Photobiol., 2003; 77(2): 186-191.

11. Caminos DA, Durantini EN, Photodynamic inactivation of Escherichia coli immobilized on agar surfaces by a tricationicporphyrin. Bioorg Med Chem., 2006; 14(12): 4253-4259.

12. Nitzan Y, Ashkenazi H, Photoinactivation of Acinetobacter baumannii and Escherichia coli B by cationic hydrophilic porphyrinat various light wavelengths. Curr Microbiol., 2001; 42(6): 408-414.

13. Sol V, Branland P, Chaleix V, Granet R, Guilloton M, Lamarche F, Verneuil B, Krausz P, Amino porphyrins as photoinhibitors of Gram-positive and -negative bacteria. Bioorg Med Chem Lett., 2004; 14(16): 4207-4211.

14. Reddi E, Ceccon M, Valduga G, Jori G, Bommer JC, Elisei F, Latterini L, Mazzucato U, Photophysical properties and antibacterial activity of meso-substituted cationic porphyrins. Photochem Photobiol., 2002; 75(5): 462-470.

15. Jori G, Camerin M, Soncin M, Guidolin L, Coppellotti O, Antimicrobial photodynamic therapy: basic principles, in: MR Hamblin, G Jori (Eds.), Photodynamic Inactivation of Microbial Pathogens, Medical and Environmental Applications, The Royal Society of Chemistry, Cambridge, UK, 2011; 1-18.

16. Maisch T, Szeimies RM, Jori G, Abels C, Antibacterial photodynamic therapy in dermatology. Photochem Photobiol Sci., 2004; 3(10): 907-917.

17. Fagadar-Cosma E, Tarabukina E, Zakharova N, Birdeanu M, Taranu B, Palade A, Creanga I, Lascu A, Fagadar-Cosma G, Hybrids formed between polyvinylpyrrolidone and an A3B porphyrin dye: behavior in aqueous solutions and chemical response to $\mathrm{CO}_{2}$ presence. Polym Int., 2016; 65(2): 200-209.

18. Fagadar-Cosma E, Enache C, Tudose R, Armeanu I, Mosoarca E, Vlascici D, Costisor O, UV-VIS and fluorescence spectra of meso-tetraphenylporphyrin and meso-tetrakis-(4-methoxyphenyl) porphyrin in $\mathrm{THF}$ and THF-water systems. The influence of $\mathrm{pH}$. Rev Chim Bucharest, 2007; 58(5): 451-455.

19. Sobczynski J, Tønnesen HH, Kristensen S, Influence of aqueous media properties on aggregation and solubility of four structurally related meso-porphyrin photosensitizers evaluated by spectrophotometric measurements. Pharmazie, 2013; 68(2): 100-109.

20. Ma HL, Jin WJ, Studies on the effects of metal ions and counter anions on the aggregate behaviors of meso-tetrakis(p-sulfonatophenyl)porphyrin by absorption and fluorescence spectroscopy. Spectrochim Acta Part A, 2008; 71(1): 153-160.

21. Li X, Li D, Zeng W, Zou G, Chen Z, Tuning Jaggregates of tetra(phydroxyphenyl) porphyrin by the head groups of ionic surfactants in acidic nonionic micellar solution. J Phys Chem B, 2007; 111(17): 4342-4348.

22. Balouiri M, Sadiki M, Ibnsouda SK, Methods for in vitro evaluating antimicrobial activity: A review. $J$ Pharmaceut Analys., 2016; 6(2): 71-79.

23. Ledeţi I, Bercean V, Alexa A, Şoica C, Şuta LM, Dehelean C, Trandafirescu C, Muntean D, Licker M, Fuliaş A, Preparation and antibacterial properties of substituted 1,2,4-triazoles. J Chem Hindawi., 2015; 879343: 1-5.

24. Danciu C, Borcan F, Soica C, Zupko I, Csányi E, Ambrus R, Muntean D, Sass C, Antal D, Toma C, Dehelean C, Polyurethane Microstructures - a Good or Bad in vitro Partner for the Isoflavone Genistein?. Nat Prod Commun., 2015; 10(6): 951-954.

25. Pavel IZ, Danciu C, Oprean C, Dehelean CA, Muntean D, Csuk R, Muntean DM, In Vitro Evaluation of the Antimicrobial Ability and Cytotoxicity on Two Melanoma Cell Lines of a Benzylamide Derivative of Maslinic Acid, Anal. Cell Pathol (Amst), 2016; 2016: 2787623: 1-6

26. Grama S, Hurduc N, Fagadar-Cosma E, Vasile M, Tarabukina E, Fagadar-Cosma G, Novel porphyrinbased polysiloxane micromaterial. Dig J Nanomat Bios., 2010; 5(4): 959-973.

27. Fagadar-Cosma E, Cseh L, Badea V, FagadarCosma G, Vlascici D, Combinatorial Synthesis and Characterization of New Asymmetric Porphyrins as Potential Photosensitizers in Photodynamic Therapy. Comb Chem High Throughput Screen CC\&HTS, 2007; 10(6): 466-472.

28. Fagadar-Cosma E, Enache C, Armeanu I, FagadarCosma G, Comparative investigations of the absorption and fluorescence spectra of tetrapyridylporphyrine and $\mathrm{Zn}$ (II) tetrapyridylporphyrine. Dig J Nanomat Bios., 2007; 2(1): 175-183.

29. Palade A, Fagadar-Cosma G, Lascu A, Creanga I, Birdeanu M, Făgădar-Cosma E, New porphyrinbased spectrometric sensor for $\mathrm{Ag} 0$ detection. Dig J Nanomat Bios., 2013; 8(3): 1013-1022.

30. Cretu C, Bucovicean C, Armeanu I, Lacrama AM, Cosma-Fagadar E, Synthesis and spectroscopic characterization of meso-tetra (3-hydroxyphenyl) porphyrin. Rev Chim Bucharest, 2008; 59(9): 979981.

31. Muthukumar P, Abraham John S, Gold nanoparticles decorated on cobalt porphyrin-modified glassy carbon electrode for the sensitive determination of nitrite ion. J Colloid Interf Sci., 2014; 421: 78-84.

32. Fagadar-Cosma E, Lascu A, Palade A, Creanga I, Fagadar-Cosma G, Birdeanu M, Hybrid material based on 5-(4-pyridyl)-10,15,20-tris(4-phenoxyphenyl)porphyrin and gold colloid for $\mathrm{CO}_{2}$ detection. Dig J Nanomat Bios., 2016; 11(2): 419-424.

33. Fagadar-Cosma E, Sebarchievici I, Lascu A, Creanga I, Palade A, Birdeanu M, Taranu B, Fagadar-Cosma G, Optical and Electrochemical Behavior of New Nano-Sized Complexes Based on Gold-Colloid and 
Co-Porphyrin Derivative in the Presence of $\mathrm{H}_{2} \mathrm{O}_{2} . J$ Alloys Compds., 2016; 686: 896-904.

34. Sebarchievici I, Lascu A, Fagadar-Cosma G, Palade A, Fringu I, Birdeanu M, Taranu B, FagadarCosma E, Optical and electrochemical mediated detection of ascorbic acid using manganese porphyrin and its gold hybrids. C R Chim., 2018; 21(3-4): 327-338.

35. Palade A, Lascu A, Fringu I, Salageanu L, Vlascici D, Birdeanu M, Fagadar-Cosma E, Comparative diclofenac detection for chronic toxicity levels using water soluble $\mathrm{Zn}$-metalloporphyrin, gold nanoparticles and their hybrid. Farmacia, 2018; 66(3): 468-476.

36. Lascu A, Birdeanu M, Taranu B, Fagadar-Cosma E, Hybrid Mn-Porphyrin-Nano Gold Nanomaterial Applied for the Spectrophotometric Detection of $\beta$ Carotene. J Chem Hindawi, 2018; 5323561: 1-11.

37. Mioc M, Soica C, Bercean V, Avram S, BalanPorcarasu M, Coricovac D, Ghiulai R, Muntean D,
Andrica F, Dehelean C, Spandidos DA, Tsatsakis AM, Kurunczi L, Design, synthesis and pharmacotoxicological assessment of 5-mercapto-1,2,4-triazole derivatives with antibacterial and antiproliferative activity. Int J Oncol., 2017; 50(4): 1175-1183.

38. Oprean C, Zambori C, Borcan F, Soica C, Zupko I, Minorics R, Bojin F, Ambrus R, Muntean D, Danciu C, Pinzaru IA, Dehelean C, Paunescu V, Tanasie G, Anti-proliferative and antibacterial in vitro evaluation of the polyurethane nanostructures incorporating pentacyclic triterpenes. Pharm Biol., 2016; 54(11): 2714-2722.

39. Făgădar-Cosma E, Făgădar-Cosma G, Vasile M, Enache C, Synthesis, spectroscopic and self-assembling characterization of novel photoactive mixed arylsubstituted porphyrin. Curr Org Chem., 2012; 16: 931-941. 